\title{
Alternative Stimulasi Kemampuan Kognitif melalui Penerapan Model Pembelajaran Berbasis Permainan Komprehensif
}

\author{
Sri Tatminingsih ${ }^{\bowtie}$ \\ Program Studi PG-PAUD,Universitas Terbuka
}

\begin{abstract}
A comprehensive game based learning model was developed by combining constructive, educational and traditional games. The implementation of this model is integrated in integrated learning strategies and is designed in such a way that it can be applied in kindergarten (TK). The game tools used are developed with the concepts contained in cognitive abilities, such as: color, shape, numbers, letters, sequences and classifications. The implementation strategy is structured in accordance with the concept. Implementation trials were carried out formatively in small groups and large groups conducted in July-September 2015 at TK Fithria in South Jakarta, Indonesia. Subjects in small group trials were teachers and children in group B. The results showed an increase in cognitive abilities of kindergarten children in group B after the application of comprehensive game-based learning. This model is an alternative learning that can be applied in the center and group and classical models. Although it can help stimulate children's abilities, the role of the teacher as a learning facilitator cannot be replaced with any media.
\end{abstract}

Keywords: Alternative Stimulation; Cognitive Children Ability; Comprehensive Games; Kindergarten

\begin{abstract}
Abstrak
Model pembelajaran berbasis permainan yang komprehensif dikembangkan dengan menggabungkan permainan yang konstruktif, edukatif dan tradisional. Implementasi model ini terintegrasi dalam strategi pembelajaran terpadu dan dirancang sedemikian rupa agar dapat diterapkan di Taman Kanak-kanak (TK). Alat permainan yang digunakan dikembangkan dengan konsep-konsep yang terkandung dalam kemampuan kognitif, seperti: warna, bentuk, angka, huruf, urutan dan klasifikasi. Strategi implementasi disusun secara terstruktur sesuai dengan konsepnya. Uji coba penerapan dilakukan secara formatif dalam kelompok kecil dan kelompok besar yang dilakukan pada bulan Juli- September 2015 di TK Fithria di Jakarta Selatan, Indonesia. Subjek dalam ujicoba kelompok kecil adalah guru dan anak kelompok B. Hasil penelitian menunjukkan adanya peningkatan kemampuan kognitif anak-anak TK kelompok B setelah penerapan pembelajaran berbasis permainan yang komprehensif. Model ini merupakan alternatif pembelajaran yang dapat diterapkan dalam model sentra maupun kelompok dan klasikal. Meskipun dapat membantu menstimulasi kemampuan anak, peran guru sebagai fasilitator pembelajaran tidak dapat digantikan dengan media apapun.
\end{abstract}

Kata Kunci: Alternatif Simulasi; Kemampuan Kognitif Anak, Permainan Komprehensif, Taman Kanak-Kanak

@ Jurnal Obsesi Prodi PG-PAUD FIP UPTT 2019

$\triangle$ Corresponding author :

Address : Jl. Cabe Raya- Pamulang-Tangerang Selatan

Email : tatmi@ecampus.ut.ac.id 
184 | Alternative Stimulasi Kemampuan Kognitif melalui Penerapan Model Pembelajaran

\section{PENDAHULUAN}

Banyak cara yang dilakukan oleh seorang pendidik untuk membantu anak didiknya mengembangkan seluruh potensinya. Setiap pendidik memiliki cara tersendiri untuk membantu menstimulasi setiap aspek perkembangan anak didiknya. Cara yang dilakukan bisa saja berbeda atau sama untuk setiap aspek perkembangan dan setiap anak bisa saja mendapatkan stimulasi yang sama atau berbeda untuk setiap aspek perkembangannya. Oleh karenanya suatu bangsa memiliki kurikulum yang daqpat digunakan oleh pendidik sebagai acuan dalam menstimulasi perkembangan anak-anak didiknya. Demikian juga dengan pendidikan pada anak usia dini. Ada kurikulum yang berlaku secara nasional di Negara Indonesia.

Kurikulum PAUD ini digunakan sebagai acuan bagi lembaga PAUD termasuk di dalamnya adalah Taman Kanak-kanak untuk membantu anak didik yang berusia 0-6 tahun mengembangkan seluruh potensinya. Meskipun demikian, pendidik di PAUD memiliki kebebasan untuk memilih cara atau metode atau strategi yang akan diterapkan pada anak didiknya.

Dalam kurikulum PAUD tahun 2013, aspek perkembangan anak usia dini yang harus dikembangkan meliputi aspek fisikmotorik, kognitif, bahasa, seni, sosialemosional, dan nilai-nilai moral dan agama. Semua aspek ini harus dikembangkan secara simultan dan berkelanjutan. Oleh karenanya pendidik perlu menyusun strategi sebaik mungkin agar seluruh aspek perkembangan anak ini dapat berkembang sesuai dengan tahap perkembangan setiap anak dan indikator masing-masing aspek.
Perkembangan kognitif, merupakan salah satu aspek yang cukup intensif dikembangkan pada anak usia dini di Indonesia. Hal ini dikarenakan masih banyak orang tua yang beranggapan bahwa anak yang memiliki kemampuan kognitif yang tingga dianggap sebagai anak cerdas yang akan berhasil pada kehidupannya kelak. Oleh karenanya hampir di semua lembaga PAUD di Indonesia menerapkan porsi yang cukup besar dalam kegiatan pengembangan kemampuan kognitif. Unsur-unsur kemampuan kognitif menurut Beaty dalam (Maxim, 1993)yang dikembangkan tersebut meliputi konsep bentuk, warna, ukuran, clasification dan seriation.

Sedangkan tujuan pengembangan kemampuan kognitif pada anak usia dini diarahkan pada kemampuan 1) auditori yaitu kemampuan yang berhubungan dengan bunyi atau indra pendengaran, 2) visual yaitu kemampuan yang berhubungan dengan penglihatan dan persepsi terhadap lingkungan, 3) taktil yaitu kemampuan yang terkait dengan indra peraba, 4) kinestetik yaitu keterampilan dalam gerakan motorik halus dan kasar, 5) aritmatika yaitu kemampuan dalam berhitung, 6) geometri adalah kemampuan yang berhubungan dengan bentuk, ukuran dan warna, serta 7) sains permulaan adalah kemampuan saintific dan pemecahan masalah secara sederhana (Nurani, 2015)

Sementara itu Dodge, Diane dan Colker, Laura J menyatakan bahwa perkembangan kognitif meliputi beberapa kemampuan, yaitu: 1) to acquire learning dan problem solving skills; 2) to expand logical thinking skills; 3) to acquire concepts and information leading to a fuller understanding of the immediate world; 4) to demonstrate skills in make believe play; 5) to expand verbal communication skills; 6) to develop 
beginning reading skills; and7) to acquire beginning reading skills( Diane $\mathrm{T}$ Dodge and Laura J Colker , 2001)

Stimulasi yang dilakukan terhadap perkembangan kognitif ini dilakukan melalui bermain dan permainan. Hal ini sesuai dengan salah satu prinsip pengembangan pada anak usia dini yaitu dilakukan melalui kegiatan yang menyenangkan dan sesuai dengan tingkat usia perkembangannya. Oleh karenanya dikembangkanlah permainan komprehensif guna menstimulasi perkembangan kognitif anak usia dini dengan cara yang menarik dan menyenangkandenganalatpermainan yang disebutStikBerwarna.

Permainan komprehensif disini merupakan gabungan dari tiga jenis permainan, yaitu permainan konstruktif, permainan edukatif dan permainan tradisional. (Hurlock, 1997) mengemukakan bahwa bermain konstuktif adalah bentuk bermain yang menggunakan bahan untuk membuat sesuatu yang bukan untuk tujuan bermanfaat melainkan lebih ditujukan bagi kegembiraan yang diperolehnya dari membuatnya. Sedangkan permainan edukatif menurut (Tedjasaputra, 2001)adalah permainan yang sengaja dirancang khusus untuk kepentingan pendidikan, dengan ciri-ciri: bersifat multiguna, ditujukan pada anak prasekolah, berfungsi mengembangkan seluruh aspek perkembangan anak, aman, mengaktifkan anak dan bersifat konstruktif. Permainan tradisional menurut (Danandjaya, 1987)adalah salah satu folkfore yang beredar secara lisan dan turun temurun dengan banyak variasi, usianya sudah tua, tidak diketahui asal usulnya dan tidak diketahui siapa pencipta permainan tersebut. Permainan tradisional yang diadopsi dalam permainan komprehensif disini adalah permainan domino, yaitu mencakup cara bermain dan bentuk kartunya.
Jadi permainan komprehensif yang dimaksud dalam artikel ini adalah alat permainan (StikBerwarna) yang menggabungkan permainan konstruktif, edukatif dan tradisional yang sengaja dirancang khusus untuk kepentingan pendidikan yang dapat melibatkan anak secara aktif, bersifat membangun dan memberikan kesempatan pada anak-anak untuk mengembangkan kemampuannya secara efektif dan sistematis. Cara bermainnya memodifikasi permainan domino dan terbuat dari kayu dengan bentuk dan ukuran sedemikian rupa berjumlah 95 keping.

Alat permainan komprehensif ini berbentuk seperti kartu domino namun terbuat dari kayu ringan dengan mengandung unsur warna dasar (merah, kuning, biru, hitam dan putih), mengandung unsur angka (angka 1, 2, 3, 4, $5,6,7,8,9,10)$, mengandung huruf alphabet mulai dari a sampai z ( a, b, c, d, e, f, d, e, f, g, h, I, j, k, l, m, n, o, p, r, s, t, $\mathrm{u}, \mathrm{w}, \mathrm{y})$, mengandung bentuk-bentuk geometri seperti lingkaran, segitiga, persegi panjang, persegi, silinder, kubus dan jajaran genjang dan mengandung unsur operasi matematika, seperti,,+- , , dan $\mathrm{x}$. Alat permainan ini aman dan sesuai dengan ukuran tangan anak dan sesuai dengan tingkat perkembangan dan usia anak.

\section{METODOLOGI}

Penelitian ini menggunakan paradigma kualitatif deskriptif dengan metode research and development yang dikembangkan oleh (Walter R Borg and Gall, M Darmien., 2007 )yang terdiri dari 9 tahapan, yaitu meliputi: 1) identify instruction $\operatorname{goal}(s) ; 2$ 2) conduct instructional analysis; 3) analyze learner and context; 4) write performance objectives; 5) develop assessment 
186 | Alternative Stimulasi Kemampuan Kognitif melalui Penerapan Model Pembelajaran

instruments; 6) develop instructional strategy; 7) develop and select instructional materials; 8) design and conduct formative evaluation of instruction; and 9) revices instruction. Namun isi artikel ini hanya merupakan hasil dari tahap ke 8 yaitu design and conduct formative evaluation of instruction. Pengembangan model pembelajaran dan alat permainan telah dilakukan pada tahap 1 hingga 7(Suparman, 2014).

Uji coba penerapan alat ini secara formatif telah dilakukan dalam kelompok kecil selama delapan pertemuan pada bulan Juli - Agustus 2015 dan kelompok besar selama 12 pertemuan pada AgustusSeptember 2015 di TK Islam Fithria Jakarta Selatan. Subjek dalam ujicoba Kelompok kecil adalah guru dan 8 anak kelompok B dan Subjek kelompok besar adalah guru dengan satu kelas kelompok B yang berjumlah 14 anak.Analisis data tentang proses penggunaan alat permainan menggunakan deskriptif kualitatif dengan catatan lapangan dan efektivitasnya dianalisis dengan persentase dan uji-t terhadap hasil asesmen awal dan asesmen akhir pada kemampuan kognitif anak menggunakan instrument asesmen kemampuankognitif yang telah dikembangkan peneliti sebelumnya

Hasil penelitian tentang permainan matematika pernahdilakukanoleh Ratih Permata sari pada tahun 2013 menyatakan bahwa kegiatan pembelajaran yang diterapkan oleh guru menggunakan konsep belajar melalui bermain baik di dalam maupun di luar secara individu atau dalam kelompok. Bermain melalui permainan dirancang dengan minat anak dan konsep yang menarik, menghasilkan rasa senang dan memprioritaskan proses daripada hasil. Kegiatan juga dirancang dengan keterlibatan aktif anak-anak dan hasil lainnya menunjukkan bahwa esensi dari kegiatan bermain matematika termasuk perasaan senang, demokratis, aktif, tidak ditegakkan, dan independen ke dalam jiwa setiap kegiatan (Sari, 2013). Hasil penelitian ini menginspirasi peneliti untuk mengembangkan model pembelajaran untuk menstimulasi kemampuan kognitif anak, termasuk di dalamnya adalah kemampuan matematika melalui kegiatan bermain yang menyenangkan, membuat anak aktif dan memunculkan kebebasan bagi anak untuk bermain.

Atin Fatimah (Fatimah, 2014) menyatakan bahwa cara bermain anak-anak dapat mendukung pengembangan dasar-dasar kecerdasan logis-matematis. Penelitian mengamati anak-anak muda dari 4-5 tahun dalam kegiatan blok dan berusaha untuk belajar tentang minat dan pertanyaan matematika spontan mereka. Prasekolah mengeksplorasi klasifikasi, pencacahan, perbandingan besar, dan pola dan bentuk. Hasilnya: frekuensi terbesar adalah dalam pola dan bentuk (21\%), magnitue (13\%), enumerasi $(12 \%)$, dinamika $(5 \%)$, hubungan spasial $(4 \%)$ dan klasifikasi (2\%). Hasil lain menunjukkan bahwa peningkatan magnitudo $(60 \%)$ adalah penghitungan terbesar, diikuti enumerasi (55\%), klasifikasi (51\%), dan pola dan bentuk (50\%). Hasil penelitian ini mendasari peneliti untuk mengembangkan alat permainan yang mengandung konsep-konsep kognitif, seperti warna, ukuran, bentuk, klasifikasi, seriasi dan symbol-simbol matematika

Erina Dwi Rahmah, (Rahmah, 2013) melakukan penelitian untuk meningkatkan kualitas pembelajaran sains dengan pendekatan inkuiri dapat meningkatkan kreativitas anak-anak dalam menggambar dan bermain bermain. Hasil penelitian ini ditunjukkan oleh peningkatan skor ratarata kreativitas. Peningkatan skor ini paling cepat terjadi pada siklus 2. Pada siklus I meningkat 2,65 atau $5,59 \%$, sedangkan pada siklus 2 sebesar 3,60 atau 7,20\%. Sedangkan dalam bermain playdough, peningkatan paling cepat juga terjadi pada 
siklus 2. Pada siklus pertama meningkat $3,05 \%$ atau $6,77 \%$ dan siklus kedua 5,95 atau $12,38 \%$.

Penelitian (Aisyah, 2017) yang bertujuan membuktikan apakah permainan warna yang diberikan kepada siswa TK dapat meningkatkan kreativitas anak dalam mewarnai gambar. Aisyah melakukan penelitian dengan mengumpukan data berupa daftar periksa dan teknik observasi dan dilakukan analisis statistic sederhana dengan menemukan persentase. Kedua penelitian ini menginspirasi peneliti untuk melakukan penelitian yang dapat mengembangkan kreativitas anak, dimana kreativitas merupakan salah satu dimensi dalam kemampuan kognitif yang perlu distimulasi dalam perkembangan anak usia dini.

Mufarizuddin melakukan penelitian untuk mengetahui peningkatan kemampuan kecerdasan matematis logika melalui permainan kartu nomor pada grup B di TK Pembina Bangkinang Kota. Subjek penelitiannya adalah anak-anak kelompok B (sebanyak 20 anak) dan guru TK pada tahun pelajaran 2015/2016. Teknik pengumpulan data menggunakan observasi, tes dan dokumentasi. Analisis data menggunakan persentase dengan teknik deskriptif (Mufarizuddin, 2017). Penelitian ini memiliki fokus penelitian tentang logika matematika pada subjek anak kelompok B. Seperti juga penelitian yang peneliti lakukan, memiliki subjek yang sama meskipun fokusnya tentang kemampuan kognitif, dimana di dalamnya terdapat pula unsure logika matematika.

\section{HASIL DAN PEMBAHASAN}

\section{UjiCoba kelompok Kecil}

Ujicoba kelompok kecil dilakukan di TK Islam Fithria Jalan Pondok Pinang III Kebayoran Lama Jakarta Selatan. Ujicoba ini dilakukan terhadap 8 anak
Kelompok B 2 dengan wali kelas Ibu Tri Rahayu, S.Pd. Ke delapan anak ini dipilih secara acak dari 12 anak didik yang berada di kelompok B2. Meskipun yang dijadikan subjek penelitian hanya delapan anak namun semua anak dilibatkan dalam kegiatan pembelajaran yang sama termasuk saat kegiatan pembelajaran dengan alat permainan Stik Berwarna. Hal ini dilakukan agar anak-anak tidak ada yang merasa iri atau menangis. Pemilihan subjek penelitian secara random.

Ujicoba kelompok kecil ini dilakukan mulai hari Senin tanggal 3 Agustus 2015 sampai 14Agustus 2015. Kegiatan pembelajaran dilakukan mengikuti putaran sentra. Hal ini dilakukan karena TK Islam Fithria menerapkan pembelajaran dengan sistem sentra. Sentra yang dimiliki oleh TK ini ada empat sentra, yaitu: sentra persiapan, sentra balok, sentra bahan alam dan sentra imtaq (iman dan taqwa). Setiap sentra dipegang oleh satu orang guru sebagai penanggung jawab. Sementara itu setiap guru bertanggung jawab atau menjadi walikelas pada satu kelas saja. Setiap kelas akan belajar di sentra yang berbeda setiap harinya dan jadwal pembagian kelas untuk masuk sentra disusun setiap satu bulan sekali dengan memperhatikan kalender dan hari libur nasional.

Pada ujicoba kelompok kecil ditemukan bahwa kemampuan kognitif anak-anak distimulasi melalui proses dalam model ini. Data hasil evaluasi formatif menunjukkan bahwa setiap anak mengalami peningkatan dalam kemampuan kognitifnya.Meskipun besarannya tidak terlalu tinggi namun tetap tampak bahwa setiap anak mengalami kemajuandenganadanya peningkatan sebesar3,39\% hingga $8,76 \%$

Hasil perhitungan uji-t terhadap kemampuan kognitif menunjukkan uji beda rataan berpasangan antara data pretes 
dan postes terlihat ada perbedaan yang signifikan ( $p$-value< $1 \%$ ) sebesar 0.272 point. Hal ini berarti bahwa ada peningkatan kemampuan kognitif anak setelah dilakukan penerapan pembelajaran berbasis permainan komprehensif secara signifikan.

Setelah dikaji lebih lanjut, ditemukan bahwa setiap anak menunjukkan perbedaaan dalam indikator yang mengalami peningkatan. Ananda Al, misalnya. Peningkatan yang dialaminya terdapat pada indikator yang menyatakan bahwa a) anak lebih sering bertanya "mengapa", b) anak mau mencoba caracara baru dalam bermain, c) anak dapat menjawab pertanyaan guru lebih cepat dan lebih benar, d) anak dapat menunjukkan gambar atau bentuk atau huruf yang sama baik bentuknya maupun warnanya, e) anak dapat memilah 4-5 benda berdasarkan warna, bentuk dan ukurannya, f) anak dapat mengurutkan balok, benda berbentuk geometri, atau melengkapi gambar berbentuk geometri berdasarkan ukuran, urutan dan bentuknya

\section{Uji Coba Kelompok Besar}

Ujicoba kelompok Besar dilakukan di TK Islam Fithria Jalan Pondok Pinang III Kebayoran Lama Jakarta Selatan. Ujicoba ini dilakukan terhadap satu kelas anak Kelompok B 1 dengan wali kelas Ibu Salis Wiwitri, S.Pd. Satu kelas anak kelompok B1 berjumlah 14 anak. Uji coba program yang dilakukan terhadap calon pengguna program sebelum program tersebut diterapkan dalam situasi pembelajaran yang sesungguhnya. Ujicoba lapangan kelompok besar ini dilakukan terhadap satu kelas kelompok B di TK Islam Fithria dengan guru-gurunya. Ujicoba lapangan ini dilakukan selama 12 kali pertemuan (tiga kali putaransentra) dengan menerapkan model pembelajaran berbasis permainan komprehensif menggunakan alat permainan Stik Berwarna. Proses penerapan mengacu pada panduan dan alat permainan komprehensif. Ujicoba dilakukan sesuai dengan rancangan pembelajaran yang telah disusun oleh peneliti. Temuan yang didapat selama uji coba kelompok besar adalah sebagai berikut.

a) Kegiatan penerapan model pembelajaran berbasis permainan komprehensif dengan alat permainan Stik Berwarna cukup beragam dan dapat diterapkan pada sentra terutama sentra persiapan, sentra balok, sentra bahan alam. Pada sentra iman dan taqwa agak tidak relevan materi dan kegiatannya namun menurut guru sentra imtaq alat permainan ini dapatdigunakan di sentra imtaq sebagai pengayaan.

b) Kegiatan dengan alat permainan Stik Berwarna menambah wawasan guru dan memberikan alternative pembelajaran yang dapat diterapkan pada anak-anak kelompok B, khususnya untuk menstimulasi kemampuan kognitif anak. Selain materinya yang sesuai untuk anak usia 5-6 tahun kegiatannya juga tidak membosankan dan disukai anak-anak.

c) Dalam menyusun kegiatan setiap guru sentra perlu berkoordinasi antara guru kelas dengan guru sentra dan sesama guru sentra agar kegiatannya tidak tumpang tindih.

Pada Uji coba kelompok Besar, terjadi peningkatan kemampuan kognitif pada 11 anak yang menjadi subjek penelitian. Kesebelas anak tersebut mengalami peningkatan mulai dari $13,5 \%$ hingga 23,4\%. Seperti juga pada uji kelompok kecil, peningkatan setiap anak terdapat pada nomor butir indikator kemampuan kognitif yang berbeda-beda. Meskipun demikian, ada tiga anak yang tidak mengalami peningkatan dalam 
kemampuan kognitifnya. Setelah dikaji lebih lanjut, ketiga anak yang belum mengalami peningkatan dalam kemampuan kognitifnya, bukan berarti bahwa ketiga anak ini tidak mendapat stimulasi atau tidak mengalami peningkatan sama sekali. Dalam beberapa kemampuan seperti dapat menjawab dengan cepat, mengenal warna, angka dan huruf serta dapat mendengarkan saat guru menjelaskan, tetap mengalami peningkatan. Ketiga anak ini memang sejak awal sudah menjadi catatan bagi guru karena berbagai alasan. Anak $\mathrm{H}$, sudah 3 tahun bersekolah di TK ini namun belum memiliki kemampuan seperti pada anakanak seumurnya. Dia belum mampu berbicara dengan lancar dan cenderung tidak bisa lepas dari ibunya. Sedangkan K, merupakan murid pindahan dari daerah Jawa Tengah, sehingga belum memahami benar bahasa Indonesia dan masih sangat bergantung pada pengantarnya (neneknya). $\mathrm{N}$ merupakan anak yang sangat pendiam dan cenderung mudah menangis (cengeng) serta masih sangat bergantung pada guru dan Ibunya. Jika Ibunya tidak muncul di sekolah maka dia akan menangis sepanjang hari. Hal inilah yang mungkin menjadi penyebab belum terjadinya peningkatan dalam kemampuan kognitif, meskipun asumsi ini belum dapat dipastikan kebenarannya karena memerlukan penelitian lebih lanjut.

Berdasarkan hasil uji-t terhadap beda rataan berpasangan antara data pretes dan postes terlihat adanya perbedaan yang signifikan ( $p$-value $<1 \%$ ) sebesar 0,425 point. Hal ini berarti bahwa ada peningkatan kemampuan kognitif anak setelah dilakukan penerapan pembelajaran berbasis permainan komprehensif secara signifikan.

\section{KESIMPULAN}

Alat permainan stik berwarna yang merupakan bagian dari perangkat model pembelajaran berbasis permainan komprehensif dapat membantu guru TK dalam menstimulasi kemampuan kognitif anak-anak kelompok B. Model pembelajaran ini dapat diterapkan pada pembelajaran sentra maupun pembelajaran klasikal kelompok. Satu hal penting dalam pembelajaran model inia dalah bahwa peran guru tidak dapat digantikan oleh media apapun

\section{UCAPAN TERIMA KASIH}

Terimakasih kami ucapkan kepada semua pihak yang berperan dalam proses penelitian ini. Terutamakepada Promotor yang telah membimbingselama proses penelitian. Segenap pimpinan dan civitas akademika Universitas Terbuka khususnya Fakultas Keguruan dan Ilmu Pendidikan dan Lembaga Penelitian dan Pengabdian Kepada Masyarakat Universitas Terbuka sertaTK Islam Fithria Jakarta Selatan.

\section{DAFTAR PUSTAKA}

Diane $\mathrm{T}$ Dodge and Laura $\mathrm{J}$ Colker . (2001). The Creative curriculum for Early Chilhood. Washington: Teaching Strategies. Inc.

Aisyah, A. (2017). Permainan Warna Berpengaruh terhadap Kreativitas Anak Usia Dini. Jurnal Obsesi Vol 1 No 2 . Riau : Universitas Tuanku Tambusai.

Danandjaya. (1987). Folkfore Indonesia. Jakarta: Gramedia.

Fatimah, A. (2014). Improving Logical Mathematical Intelligence Through Block Play. Prociding The Pasific Early Childhood Education Research Association: Living Harmony Throuhg Early Childhood Education and Care. 15th Annual Conference. August 8-10th . Bali: ECERA. 
190 | Alternative Stimulasi Kemampuan Kognitif melalui Penerapan Model Pembelajaran

Hurlock, E. (1997). Child Development 6th Ed. Tokyo: Mc.Graw Hill Inc. International Student Ed.

Maxim, G. (1993). The Young Children: Guiding Children From Infancy Through The Early Years. New York: Mc. Millan Publishing Co. .

Mufarizuddin. (2017). Peningkatan Kecerdasan Logika Matematika Anak Melalui Bermain Kartu Angka Kelompok $B$ di TK Bangkinang. Jurnal Obsesi Vol 1 No 1. Riau: Universitas Tuanku Tambusai.

Nurani, Y. (2015). Metode Pengembangan Kognitif. . Jakarta: Universitas Terbuka.

Rahmah, E. D. (2013). Peningkatan Kreativitas melalui Pendekatan Inquiry dalam Pembelajaran Sains: Penelitian Tindakan di TK Bintang Kecil Kelompok B Tahun 2013). Jurnal Pendidikan Usia Dini Volume 7 No. 2. Jakarta: Universitas Negeri Jakarta.

Sari, R. P. (2013). Kegiatan Bermain Matematika (Studi Kasus Kelompok A di TK RA Kartini Aisiyah 21, Kota MalangTahun 2013), Jurnal Pendidikan Usia Dini. Volume 7 No 2 November. . Jakarta: Universitas Negeri Jakarta.

Suparman, A. (2014). Desain Instruksional Modern. Jakarta, Jakarta, Indonesia: Erlangga.

Tedjasaputra. (2001). Bermain, Mainan dan Permainan untuk Pendidikan Usia Dini. . Jakarta: Grasindo.

Walter R Borg and Gall, M Darmien. (2007 ). Educational Research. An Introduction. New York:: Pitman PublishingInc. 